\title{
A CRUEL PEDAGOGIA DO VÍRUS
}

\section{SANTOS, Boaventura de Sousa. A Cruel Pedagogia do Virus.}

Coimbra: Almedina, 2020. Impresso em 2020. 32 páginas

A cruel Pedagogia do vírus, livro do sociólogo português, Boaventura de Sousa Santos, lançado neste ano de 2020 pela Editora Almedina, traz de forma reflexiva e oportuna, para o momento em que vivemos, narrativas contemporâneas e resgates históricos que nos levam a habitar outros tempos e espaços, para entendermos melhor a constituição dessa e de outras pandemias que têm nos assolados nos últimos tempos, tomando como análise crítica uma das matrizes de inteligibilidade do capitalismo, o neoliberalismo. É um livro-convite à vida que nos leva a refletir sobre nossos comportamentos e relações, abrindo possiblidades para uma nova "normalidade".

Numa versão compacta, o livro consegue apresentar uma discussão necessária para nossa atual realidade, trazendo questionamentos e reflexões, além de instigar o leitor a pensar e analisar acontecimentos cotidianos e suas repercussões na sociedade, provocando um melhor entendimento da constituição dos fatos, bem como suscitando possibilidades e alternativas perante caminhos a serem tomados.

A obra é dividida em cinco capítulos que se relacionam por meio de questionamentos a crises, pandemias e quarentenas vividas pela sociedade contemporânea há décadas. Dessa forma, traz como pano de fundo para discussão o cenário socioeconômico, expondo o poder do vírus e a vulnerabilidade humana, e nos mostra que o que seria impossivel de repente se torna possivel.

No primeiro capítulo intitulado "Vírus: tudo o que é sólido se desfaz no ar", o autor inicia seu pensamento questionando a normalidade da sociedade contemporânea, a qual nomeia como "normalidade de exceção", por ser constituída em um estado permanente de crise, o que não se opõe à crise da atual pandemia. Nesse sentido, Santos (2020, p. 1) coloca que o mundo vive, desde a década de 1980, uma crise global permanente "à medida que o neoliberalismo se foi impondo como a versão dominante do capitalismo". Assim, ele caracteriza tais crises como passageira e permanente, em que a primeira parte de fatores que a provocam e chega a ser superada em um dado momento; a segunda, se constitui como justificativa para tudo pelos governantes, principalmente, no que diz respeito a melhorias sociais. A manutenção dessa crise tem como objetivo a sua não resolutividade, de forma a legitimar concentrações de riquezas e o travamento de medidas de controle ecológico.

Etimologicamente, o termo "pandemia" significa "todo o povo", trazendo consigo a ideia de solidariedade e ratificando o sentido de democracia, o que é questionável quando as medidas de segurança são o isolamento uns dos outros. Dessa forma, a pandemia não é uma crise, ela vem apenas agravar uma situação de crise de modos de viver dominantes, sejam eles uns sobre os outros ou sobre a natureza.

Ao observamos mais de perto momentos de crise, nos deparamos com uma espécie de elasticidade do corpo social, jamais imaginada que seria possivel, pois as pandemias, os desastres ambientais e os colapsos econômicos, geralmente oferecem alternativas de vida às pessoas. Santos $(2020$, p. 2 ) coloca que "a ideia conservadora de que não há alternativa 
ao modo de vida imposto pelo hipercapitalismo em que vivemos cai por terra". Isso se dá, a um abrandamento da economia, o qual deixa escapar fatores positivos como solidariedade, cooperação, diminuição da poluição etc.

$O$ autor conclui esse primeiro capítulo, chamando a atenção para a guerra comercial e de interesses entre os Estados Unidos e a China, bem como a constituição dos discursos por meio da mídia e desloca os olhares da comoção social da pandemia para as sombras que a visibilidade cria, citando como exemplo a vulnerabilidade dos refugiados e imigrantes.

O segundo capítulo, "A trágica transparência do vírus", apresenta-se como uma crítica à política, que tem abandonado seu lugar de interlocução nas discussões entre cultura e ideologia, se distanciando cada vez mais da realidade da maioria da população na ânsia de atender a aspirações dos mercados. Assim, ao mesmo tempo que sentimos medo generalizado da morte sem fronteiras, causada por um inimigo invisível, podemos enxergar a pandemia como uma luz na escuridão que vivemos, que pode nos conduzir a outros caminhos.

Ainda nesse capítulo, o autor faz uma analogia interessante do vírus com o mercado, em que ambos são poderosos, insidiosos e imprevisíveis, marcando uma espécie de último reinado, com sua trindade constituída por Deus, o vírus e os mercados, e só ascendem à salvação os mais fortes, santos, ricos e jovens. Daí, os seres humanos se configurarem como hospedeiros frágeis para esses seres invisíveis, correndo o risco de se tornarem uma espécie em extinção.

No "Sul da quarentena", capítulo três, são expostas condições de vida de grupos vulneráveis que vivem em quarentena social permanente, sofrendo discriminação e formas de dominação desumanas, dificultando, ainda mais, o enfrentamento dessas condições com $\mathrm{o}$ isolamento social exigido durante a pande- mia. Nesses grupos, podemos encontrar: as mulheres e o aumento da violência doméstica; os trabalhadores autônomos, que precisam escolher morrer do vírus ou de fome; os trabalhadores de rua, que sem vida na rua não têm como garantir sua subsistência; os sem-teto, moradores de periferias pobres, refugiados, pessoas com deficiência e idosos que já vivem em quarentena permanente ou imposta pela sociedade, familiares ou o sistema. Pensando nisso, as normas recomendadas pela Organização Mundial de Saúde (OMS) ficam inviáveis de serem atendidas por quem não tem as condições mínimas de sobrevivência, pois para esses grupos a atual emergência de saúde vem juntar-se a muitas outras emergências.

O penúltimo capítulo, “A intensa Pedagogia do vírus: as primeiras lições", ilustra percepções da sociedade contemporânea aos riscos que correm, utilizando as crises para ilustrar a comoção provocada pelos meios midiáticos e o poder dos discursos políticos. Porém, deixa escapar que as pandemias não matam tão indiscriminadamente quanto se prega, pois, crises crônicas e com um grau maior de letalidade, tendem a passar despercebidas com mais frequência.

A discussão central desse capítulo concentra-se no modelo social e econômico aos quais estamos envolvidos, o que nos serve de subsídio para um melhor entendimento dos comportamentos da sociedade contemporânea.

Historicamente, conhecemos das páginas dos livros à vida prática os modos de dominação como o capitalismo, colonialismo e patriarcado. Eles operam sempre em conjunto e são omnipresentes e invisiveis na vida dos seres humanos, sendo possivel visualizá-los apenas nas suas consequências, por meio da desigualdade social e destruição do planeta. Por mais que, em alguns momentos ou lugares, possam demonstrar fracos ou mortos, eles 
sempre estão vivos e fortes para emergir nos momentos de crises.

Appadurai (2009) discute esses modos de dominação, especificamente o capitalismo, na sua versão mais globalizada e violenta de ser, nos mostrando a incerteza social e a insegurança dos estados advindas da economia como fator desencadeador de genocídios. 0 autor chama ainda de "pequeno número" classes sociais dominantes infiltradas na multidão, esperando o momento certo para emergir e se estabelecer nos regimes totalitários. Para isso, utiliza-se de eventos de risco, como as pandemias, por exemplo, associados à comoção da população por meio de veículos midiáticos e discursos do diferente como ameaça, disseminando um verdadeiro estado de terrorismo na população.

Nesse contexto, o neoliberalismo crescente e dominado pelo capital financeiro impõe sua versão mais cruel à sociedade, levando a saúde, educação e segurança social ao modelo de negócio capital, disseminando a lógica que qualquer serviço público está aquém de atender com qualidade às necessidades da sociedade atual, assim, ignoram totalmente os princípios de cidadania e direitos humanos, promovendo a mercantilização da vida coletiva. Corroborando com Santos (2020, p. 24), ele caracteriza esse pensamento, elencando:

[...] a demonização dos serviços públicos (o Estado predador, ineficiente ou corrupto); a degradação das políticas sociais ditada pelas políticas de austeridade sob o pretexto da crise financeira do Estado; a privatização dos serviços públicos e o subfinanciamento dos que restaram por não interessarem ao capital.

Dessa forma, podemos visualizar uma população indefesa, propensa a mais endividamentos, um Estado com sua capacidade de intervenção diminuída e um futuro com outras tantas epidemias, consequências, não provocadas pela pandemia, mas por políticas neoliberais que sugam dos seres humanos o exercício de seus direitos como cidadãos. Assim, vemos uma valorização dos corpos mais necessários à economia, o crescimento da vulnerabilidade da maioria das pessoas, as quais sequer, os cuidados com a saúde e as necessidades básicas são atendidos, evidenciando a importância dos problemas globais apenas quando atingem as populações dos países ricos.

Nessa esteira de pensamento, o autor chega, ao quinto e último capítulo do livro, o qual intitula de "O futuro pode começar hoje". o tema é bastante sugestivo e nos faz pensar que caminhos são possiveis a qualquer tempo, o que nos dá a ideia que podemos navegar por outras rotas diante de turbulências e obstáculos encontrados. Se tomarmos a pandemia que nos assola e a quarentena que vivemos como exemplo, ambas nos mostram essa viabilidade devido a mudanças de comportamento que fomos obrigados a assumir em tempos considerados impossiveis de tais condutas. Dessa forma, nos leva a pensar em possibilidades de um novo modo de viver, de produzir, de consumir e de conviver, que pode evitar novas pandemias e tragédias.

Santos (2002) corrobora nesse sentido quando apresenta a sociologia das ausências, que tem como objetivo transformar objetos impossiveis em possiveis, ou seja, as ausências em presenças, revelando as riquezas das experiências sociais do mundo, antes negligenciadas e não socializadas pela razão metonímica.

Portanto, diante do exposto neste texto, podemos observar que há uma necessidade urgente de estabelecermos um novo contrato de parceria entre os processos políticos e civilizatórios, senão a Covid-19 vai passar e vamos continuar vivendo em quarentena política, cultural e ideológica de um capitalismo fechado em si próprio. Logo, ideias e alternativas irão surgir, 
cabe saber se vamos concretizá-las ou voltar ao mesmo, vivendo o chamado "novo normal", com os mesmos protestos, as mesmas desigualdades, a mesma corrupção e falta de proteção social, o que será justificado pela velha crise financeira: a pandemia das pandemias.

\section{Referências}

APPADURAI, Arjun. 0 medo ao pequeno número: ensaio sobre a geografia da raiva. Trad. Ana Goldber- ger. São Paulo: Iluminuras, Itaú Cultural, 2009.

SANTOS, Boaventura de Sousa. A Cruel Pedagogia do Virus. Coimbra: Almedina, 2020.

SANTOS, Boaventura de Souza. Para uma sociologia das ausências e uma sociologia das emergências. Revista Crítica de Ciências Sociais, Coimbra, Centro de Estudos Sociais da Universidade de Coimbra, 63, p. 237-280, out 2002.

Recebido em: $11 / 05 / 2020$

Revisado em: 30/08/2020

Aprovado em: 02/09/2020

Francisco Varder Braga Junior é doutorando no Programa de Pós-Graduação em Educação pela Universidade de Santa Cruz do Sul (Unisc). Membro do grupo de pesquisa cadastrado no Diretório do Conselho Nacional de Desenvolvimento Científico e Tecnológico (CNPq): Políticas Públicas, Inclusão e Produção de Sujeitos da UNISC. E-mail: varder.braga@ ufersa.edu.br 